\title{
Atmospheric circulation during heat waves in Eastern Europe
}

\author{
ARKADIUSZ M. TOMCZYK
}

Adam Mickiewicz University, Institute of Physical Geography and Environmental Planning, Department of Climatology, B. Krygowskiego 10, 61-680 Poznań, Poland; e-mail: atomczyk@ amu.edu.pl

ABSTRACT This article aims to describe heat waves in Eastern Europe and to determine the synoptic situations which cause them. In this article, a hot day is defined as the one with a maximum temperature above the $95^{\text {th }}$ percentile of all the values in the analysed period, and a heat wave is considered as a sequence of at least 5 such days. In the analysed period and within the investigated area, from 24 (Kaliningrad) to 55 (Kharkiv) heat waves were observed. The longest heat wave was recorded in Moscow in 2010, lasting as many as 45 days. In the analysed period, an increase in frequency and length of heat waves was observed within the analysed area. The occurrence of heat waves was connected with a high pressure system located over the eastern part of the continent, during which positive anomalies of sea level pressure and the $500 \mathrm{hPa}$ geopotential height as well as positive T850 anomalies were recorded.

KEY WORDS air temperature - heat waves - climate changes - Eastern Europe

томсZYк, А. M. (2017): Atmospheric circulation during heat waves in Eastern Europe. Geografie, 122, 2, 121-146.

Received May 2016, accepted January 2017.

C Česká geografická společnost, z. s., 2017 


\section{Introduction}

According to the Fifth IPCC Assessment Report (2013), the increase in global average temperature between 1880 and 2012 was $0.85^{\circ} \mathrm{C}$, and the first decade of the $21^{\text {st }}$ century was the warmest since the beginning of instrumental measurement. One manifestation of the observed warming is the increasing frequency of occurrence of extremely hot days and heat waves (Unkašević, Tošić 2009; Kyselý 2010; Shevchenko et al. 2014; Spinoni et al. 2015; Unkašević, Tošić 2015; Tomczyk, Bednorz 2016). Model studies have shown that heat waves in the $21^{\text {st }}$ century are not only going to be more frequent but also longer and more intense (Meehl, Tebaldi 2004; Koffi, Koffi 2008; Kürbis et al. 2009; Kyselý 2010; Pongracz, Bartholy, Bartha 2013; Acar Deniza, Gönençgil 2015; Zacharias, Koppe, Mücke 2015). According to Barriopedro et al. (2011) the "mega heat waves" which occurred in 2003 and 2010 resulted in more than 500-year seasonal air temperature records across approximately $50 \%$ of the area of Europe. The summer of 2010 should be considered as an extreme weather phenomenon with regard to especially unfavourable biometeorological conditions and serious economic effects (Twardosz, Kossowska-Cezak 2013).

Atmospheric circulation is one of the most important factors influencing weather and climate conditions (Niedźwiedź 1981, Yarnal 1993). As BielecBąkowska (2010) emphasised, an important characteristic of the circulation over Europe is the occurrence of high pressure systems and, especially, zonal circulation blocking patterns characterised by considerable persistence. The last decades have shown a sharp increase in the frequency of blocking patterns over Europe and their influence on a decrease in the number of low pressure systems to the south of $55^{\circ} \mathrm{N}$ (Leckebusch, Ulbrich 2004; Leckebusch et al. 2008; BielecBąkowska 2014). Blocking patterns in summer contribute to the occurrence of heat waves and, in winter, to the occurrence of cold waves (Porębska, Zdunek 2013). The influence of atmospheric circulation on temperature conditions, and the occurrence of thermal extremes, have been a subject of scientific interest for a long time (Founda, Giannakopoulos 2009; Ustrnul, Czekierda, Wypych 2010; Kažys et al. 2011; Bednorz, Kolendowicz 2013; Porębska, Zdunek 2013; Unkašević, Tošić 2015).

In recent years, climatology literature has seen a clear increase in interest regarding extreme weather events, including heat waves. Studies conducted to date on such weather conditions in Eastern Europe have mainly been concerned with 2010 heat waves in Russia and their influence on mortality (Grumm 2011; Dole et al. 2011; Otto et al. 2012). For this reason, a study was undertaken of the occurrence of heat waves in Eastern Europe using a longer data series, in order to find changes in their occurrence. With regard to the great threat posed to human health and life by the occurrence of heat waves, as well as to the high social and 
economic costs of the consequences of heat waves, the presented research results may turn out to be interesting to a wide and diverse readership.

The main objective of this article was to determine the circulation conditions which are favourable to the occurrence of heat waves in Eastern Europe. The achievement of this objective was preceded by defining the multi-annual variability of a number of hot days and heat waves within the analysed area between 1973 and 2010.

\section{Data and methodology}

The research study used daily data on maximum $\left(T_{\max }\right)$ and minimum $\left(T_{\min }\right)$ for 33 stations located in Eastern Europe (Belarus, Estonia, Lithuania, Latvia, Russia and Ukraine) within the period between 1973 and 2010 (Fig. 1, Table 1). The data were obtained from the freely-accessible databases of the National Oceanic and Atmospheric Administration (NOAA). Data from NOAA sources have been subjected to quality control (QC) procedures, in accordance with the metadata regulation (http://www7.ncdc.noaa.gov/CDO/GSOD_DESC.txt).

Despite their occurrence in many regions of the world, heat waves do not have a concise and universal definition, and they are defined variously in different countries (Kozłowska-Szczęsna, Krawczyk, Kuchcik 2004). In Słownik Meteorologiczny [Meteorological Lexicon] (Niedźwiedź 2003) a heat wave is defined as a several-day or several-week period of maximum air temperatures exceeding $30.0^{\circ} \mathrm{C}$, alternated with short cooler periods. A more precise definition is provided by Glossary of Meteorology (Glickmann, ed. 2000), where a heat wave is described as at least a three-day period of maximum temperature $\geq 32.2^{\circ} \mathrm{C}\left(90^{\circ} \mathrm{F}\right)$. A heat wave (temperature wave) can also be defined as a period of 5 consecutive days with a temperature $>22.7^{\circ} \mathrm{C}$ including at least three days with a temperature $>25^{\circ} \mathrm{C}$ (Ozheredov et al. 2010). Besides this, a heat wave can also be defined as a six-day period of apparent temperature (AT) above the $95^{\text {th }}$ percentile and beginning with a temperature increase of at least $2.0^{\circ} \mathrm{C}$ on the previous day (Kuchcik, Degórski 2009), or as a period $>5$ consecutive days with $\mathrm{T}_{\max }>5^{\circ} \mathrm{C}$ above the 1961-1990 daily $\mathrm{T}_{\max }$ normal (IPCC 2001; Frich et al. 2002; Unkašević, Tošić 2009).

A weather phenomenon which is so rare within a particular area and in a particular season that it lies within the range of below the $10^{\text {th }}$ or above $90^{\text {th }}$ percentile of an observed probability density function or rarer is defined as an extreme weather event (IPCC 2007). On this basis, in this article, a hot day was defined as a day with the maximum temperature above the $95^{\text {th }}$ percentile of all the values in the analysed multiannual period, while a heat wave was defined as a sequence of at least 5 days of that kind. In the analysed multiannual period, the value of the $95^{\text {th }}$ annual percentile fluctuated within the discussed area from $20.4^{\circ} \mathrm{C}$ (Murmansk) 


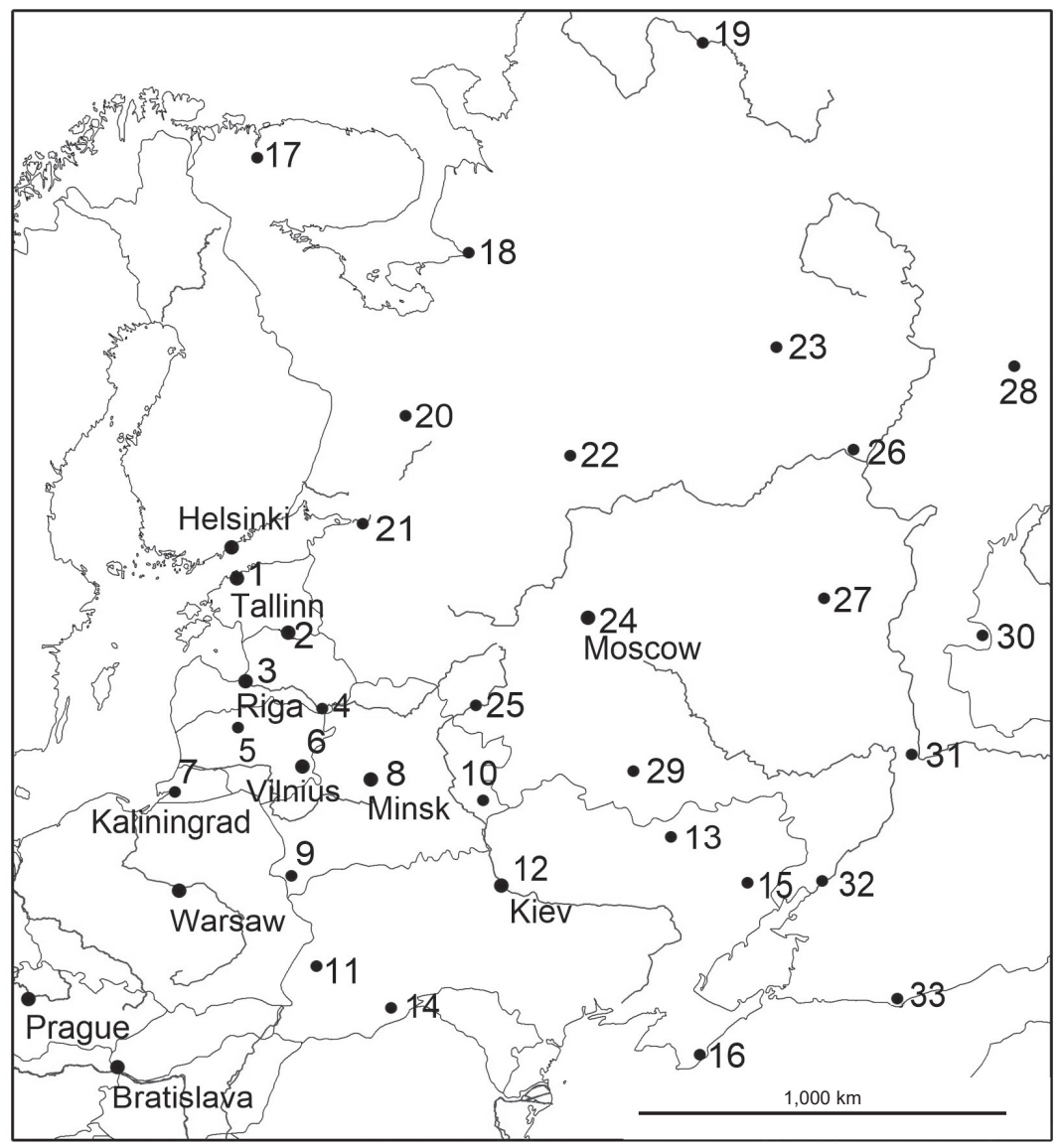

Fig. 1 - Locations of the meteorological stations

to $33.7^{\circ} \mathrm{C}$ (Aleksandrov-Gaj; Fig. 2a). The aforementioned definition was adopted in studies concerning, among others, the occurrence of heat waves on the south coast of the Baltic Sea (Tomczyk, Bednorz 2014a) and in Central Europe (Tomczyk, Bednorz 2016).

On the basis of source material, basic climatological characteristics were calculated, i.e. average maximum air temperature and $\mathrm{T}_{\max }$ anomalies. Anomalies were calculated as the difference between the average $T_{\max }$ of a given season (or $T_{\max }$ of a given day) and the average $T_{\max }$ for the multi-year period. Hot days were also determined, from among which heat waves were identified. Then, variability in the identified characteristics over the multi-year period was analysed, and linear trends and their statistical significance were calculated. On the other hand, to determine the statistical significance of the slope coefficient, the t-Student test at the level of $\mathrm{p} \leq 0.05$ was applied. 
Table 1 - List of the meteorological stations

\begin{tabular}{|c|c|c|c|c|}
\hline No. & Station & Latitude & Longitude & Elevation ( $m$ a.s.l.) \\
\hline 1 & Tallinn & $59^{\circ} 24^{\prime} 46^{\prime \prime} \mathrm{N}$ & $24^{\circ} 49^{\prime} 58^{\prime \prime} \mathrm{E}$ & 39.9 \\
\hline 2 & Valga & $57^{\circ} 46^{\prime} 58^{\prime \prime} \mathrm{N}$ & $26^{\circ} 01^{\prime} 58^{\prime \prime} \mathrm{E}$ & 66.0 \\
\hline 3 & Riga & $56^{\circ} 58^{\prime} 01^{\prime \prime} \mathrm{N}$ & $24^{\circ} 03^{\prime} 00^{\prime \prime} \mathrm{E}$ & 26.0 \\
\hline 4 & Daugavpils & $55^{\circ} 52^{\prime} 01^{\prime \prime} \mathrm{N}$ & $26^{\circ} 37^{\prime} 01^{\prime \prime} \mathrm{E}$ & 122.0 \\
\hline 5 & Siauliai & $55^{\circ} 55^{\prime} 58^{\prime \prime} \mathrm{N}$ & $23^{\circ} 18^{\prime} 57^{\prime \prime} \mathrm{E}$ & 138.0 \\
\hline 6 & Vilnius & $54^{\circ} 38^{\prime} 02^{\prime \prime} \mathrm{N}$ & $25^{\circ} 17^{\prime} 09^{\prime \prime} \mathrm{E}$ & 196.4 \\
\hline 7 & Kaliningrad & $54^{\circ} 42^{\prime} 00^{\prime \prime} \mathrm{N}$ & $20^{\circ} 30^{\prime} 00^{\prime \prime} \mathrm{E}$ & 21.0 \\
\hline 8 & Minsk & $53^{\circ} 51^{\prime} 54^{\prime \prime} \mathrm{N}$ & $27^{\circ} 32^{\prime} 24^{\prime \prime} \mathrm{E}$ & 227.9 \\
\hline 9 & Brest & $52^{\circ} 06^{\prime} 28^{\prime \prime} \mathrm{N}$ & $23^{\circ} 53^{\prime} 52^{\prime \prime} \mathrm{E}$ & 142.6 \\
\hline 10 & Gomel & $52^{\circ} 31^{\prime} 37^{\prime \prime} \mathrm{N}$ & $31^{\circ} 01^{\prime} 01^{\prime \prime E}$ & 143.9 \\
\hline 11 & Lviv & $49^{\circ} 49^{\prime} 00^{\prime \prime} \mathrm{N}$ & $23^{\circ} 57^{\prime} 00^{\prime \prime E}$ & 326.4 \\
\hline 12 & Kiev & $50^{\circ} 24^{\prime} 00^{\prime \prime} \mathrm{N}$ & $30^{\circ} 31^{\prime} 59^{\prime \prime} \mathrm{E}$ & 125.0 \\
\hline 13 & Kharkiv & $49^{\circ} 55^{\prime} 26^{\prime \prime} \mathrm{N}$ & $36^{\circ} 17^{\prime} 20^{\prime \prime} \mathrm{E}$ & 154.0 \\
\hline 14 & Chernivtsi & $48^{\circ} 22^{\prime} 00^{\prime \prime} \mathrm{N}$ & $25^{\circ} 54^{\prime} 00^{\prime \prime} \mathrm{E}$ & 246.0 \\
\hline 15 & Donetsk & $48^{\circ} 04^{\prime} 12^{\prime \prime} \mathrm{N}$ & $37^{\circ} 46^{\prime} 12^{\prime \prime} \mathrm{E}$ & 225.0 \\
\hline 16 & Simferopol & $44^{\circ} 42^{\prime} 00^{\prime \prime} \mathrm{N}$ & $34^{\circ} 07^{\prime} 58^{\prime \prime E}$ & 181.0 \\
\hline 17 & Murmansk & $68^{\circ} 46^{\prime} 55^{\prime \prime} \mathrm{N}$ & $32^{\circ} 45^{\prime} 03^{\prime \prime} E$ & 81.1 \\
\hline 18 & Arkhangelsk & $64^{\circ} 36^{\prime} 00^{\prime \prime} \mathrm{N}$ & $40^{\circ} 42^{\prime} 57^{\prime \prime} \mathrm{E}$ & 18.9 \\
\hline 19 & Pechora & $65^{\circ} 07^{\prime} 58^{\prime \prime} \mathrm{N}$ & $57^{\circ} 07^{\prime} 58^{\prime \prime} \mathrm{E}$ & 53.2 \\
\hline 20 & Petrozavodsk & $61^{\circ} 49^{\prime} 01^{\prime \prime} \mathrm{N}$ & $34^{\circ} 16^{\prime} 01^{\prime \prime} \mathrm{E}$ & 110.0 \\
\hline 21 & Saint Petersburg & $59^{\circ} 48^{\prime} 00^{\prime \prime} \mathrm{N}$ & $30^{\circ} 37^{\prime} 33^{\prime \prime} \mathrm{E}$ & 24.0 \\
\hline 22 & Vologda & $59^{\circ} 13^{\prime} 58^{\prime \prime} \mathrm{N}$ & $39^{\circ} 52^{\prime} 01^{\prime \prime E}$ & 131.0 \\
\hline 23 & Kirov & $58^{\circ} 39^{\prime} 00^{\prime \prime} \mathrm{N}$ & $49^{\circ} 36^{\prime} 00^{\prime \prime} \mathrm{E}$ & 147.0 \\
\hline 24 & Moscow & $55^{\circ} 35^{\prime} 27^{\prime \prime} \mathrm{N}$ & $37^{\circ} 15^{\prime} 39^{\prime \prime} \mathrm{E}$ & 208.8 \\
\hline 25 & Smolensk & $54^{\circ} 45^{\prime} 00^{\prime \prime} \mathrm{N}$ & $32^{\circ} 04^{\prime} 01^{\prime \prime} \mathrm{E}$ & 239.0 \\
\hline 26 & Kazan & $55^{\circ} 36^{\prime} 21^{\prime \prime} \mathrm{N}$ & $49^{\circ} 16^{\prime} 44^{\prime \prime E}$ & 126.2 \\
\hline 27 & Penza & $53^{\circ} 07^{\prime} 58^{\prime \prime} \mathrm{N}$ & $45^{\circ} 01^{\prime} 01^{\prime \prime} \mathrm{E}$ & 174.0 \\
\hline 28 & Ufa & $54^{\circ} 33^{\prime} 28^{\prime \prime} \mathrm{N}$ & $55^{\circ} 52^{\prime} 26^{\prime \prime} \mathrm{E}$ & 136.9 \\
\hline 29 & Kursk & $51^{\circ} 46^{\prime} 01^{\prime \prime} \mathrm{N}$ & $36^{\circ} 10^{\prime} 01^{\prime \prime} \mathrm{E}$ & 247.0 \\
\hline 30 & Aleksandrov-Gaj & $50^{\circ} 09^{\prime} 00^{\prime \prime} \mathrm{N}$ & $48^{\circ} 33^{\prime} 00^{\prime \prime} \mathrm{E}$ & 25.0 \\
\hline 31 & Volgograd & $48^{\circ} 46^{\prime} 55^{\prime \prime} \mathrm{N}$ & $44^{\circ} 20^{\prime} 42^{\prime \prime} \mathrm{E}$ & 146.9 \\
\hline 32 & Rostov-on-Don & $47^{\circ} 15^{\prime} 00^{\prime \prime} \mathrm{N}$ & $39^{\circ} 49^{\prime} 01^{\prime \prime} \mathrm{E}$ & 78.0 \\
\hline 33 & Sochi & $43^{\circ} 27^{\prime} 00^{\prime \prime} \mathrm{N}$ & $39^{\circ} 57^{\prime} 25^{\prime \prime} \mathrm{E}$ & 27.1 \\
\hline
\end{tabular}

To describe pressure conditions favouring the occurrence of heat waves, daily values of sea level pressure (SLP), the height of the geopotential height of $500 \mathrm{hPa}$ $(\mathrm{Z} 500 \mathrm{hPa})$, and temperature on the $850 \mathrm{hPa}$ pressure surface (T850) were used. The data were obtained from the records of the National Center for Environmental Prediction/National Center for Atmospheric Research (NCEP/NCAR) Reanalysis (Kalnay et al. 1996), which are available in Climate Research Unit resources. On the basis of the above-mentioned data, the SLP, Z500 hPa and T850 maps for the summer season (June-August) and a composite map for hot days forming heat 
waves were drawn up. The description was supplemented with maps of anomalies. Anomalies were defined as a difference between mean SLP, Z500 hPa and T850 values for heat waves and the mean values of these characteristics in the summers of the analysed period. Only days on which the temperature met the criterion of a hot day in at least $25 \%$ of stations were selected for analysis. Additionally, a similar description was conducted for the longest heat wave recorded within the analysed area. The circulation types were divided by clustering hot days by sea-level pressure values, applying the minimal variance method, also known as Ward's method. This method is based on Euclidean distances, and in essence involves merging the pair of clusters A and B which, after merging, provide the minimum sum of squares of all objects' deviations from the newly-created cluster's centre of gravity (Ward 1963). In order to achieve that, standardised SLP values were used. Standardisation was carried out to deseasonalise the observations, while maintaining the intensity of pressure field (Esteban et al. 2005). Grouping methods, including Ward's method, are often applied in climatology, e.g. in determining seasonal and climatic regions, and identifying weather types (Tomczyk 2014; Bednorz, Wibig 2015). Maps of SLP, Z500 hPa and T850 - and maps of anomalies - were drawn up for the identified circulation types.

\section{Results}

\subsection{The maximum temperature in the summer}

Between 1973 and 2010, in Eastern Europe, the mean $\mathrm{T}_{\max }$ in the summer season (June-August) was $22.8^{\circ} \mathrm{C}$ and ranged from $15.0^{\circ} \mathrm{C}$ in Murmansk to $29.1^{\circ} \mathrm{C}$ in Aleksandrov-Gaj (Fig. $2 \mathrm{~b}$ ). In the analysed period, on average, the warmest summer was recorded in 2010, and the mean $\mathrm{T}_{\max }$ in this season fluctuated from $15.7^{\circ} \mathrm{C}$ (Murmansk) to $35.4^{\circ} \mathrm{C}$ (Aleksandrov-Gaj). When analysing the mean $\mathrm{T}_{\max }$ in the individual stations one can notice that the summer of 2010 was the warmest mainly in Russia and Ukraine. The warmest summer was recorded in 2002 in the Baltic countries, among others, while in the Arkhangelsk and Pechora stations it was recorded in 1974. In $60 \%$ of the stations the coldest summer occurred in the 1970s. The lowest mean $\mathrm{T}_{\max }$ in Eastern Europe was observed in the summer of $1978\left(20.6^{\circ} \mathrm{C}\right)$ and $1976\left(20.7^{\circ} \mathrm{C}\right)$. The course of the mean $\mathrm{T}_{\max }$ in the analysed years showed considerable year-to-year fluctuations. Within the majority of the investigated area, the variability of the mean $\mathrm{T}_{\max }$ was similar, as is proven by the low diversity of standard deviation values, ranging from 1.3 to 1.6. The research showed a statistically significant increase in $\mathrm{T}_{\max }$ within the majority of the analysed area, fluctuating from $0.30^{\circ} \mathrm{C} / 10$ years (Arkhangelsk) to $1.07^{\circ} \mathrm{C} / 10$ years (Simferopol; Fig. 2c, Fig. 3). Only in Pechora was a small decrease in the mean 
(a)

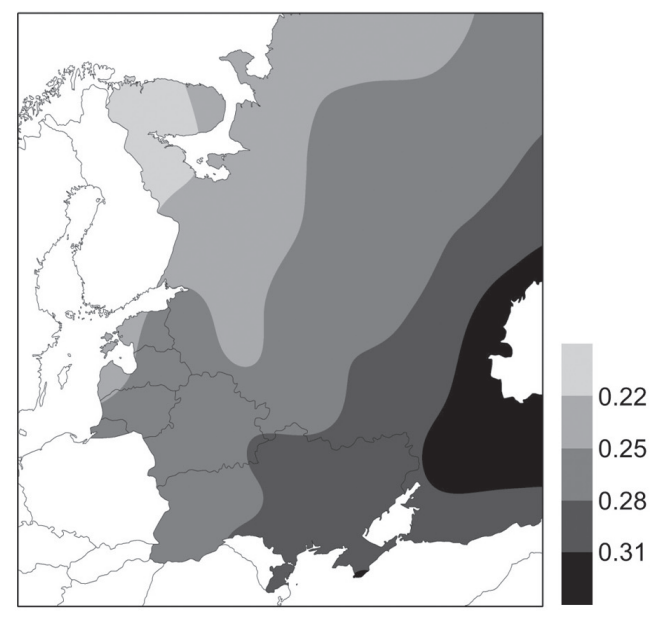

(b)

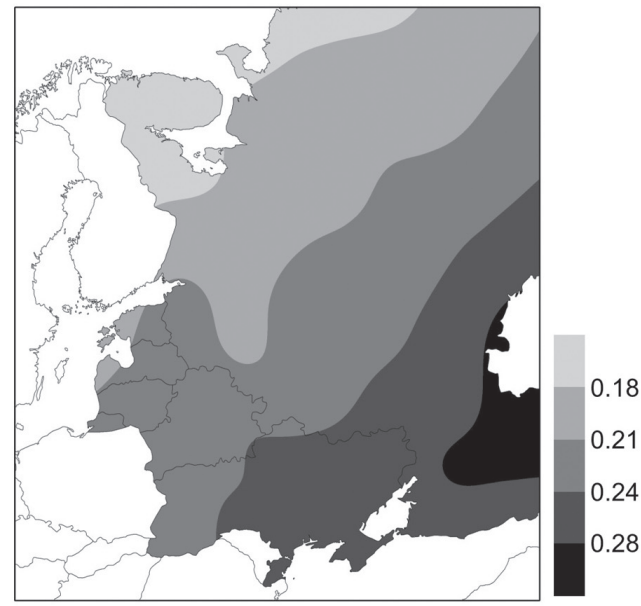

(c)

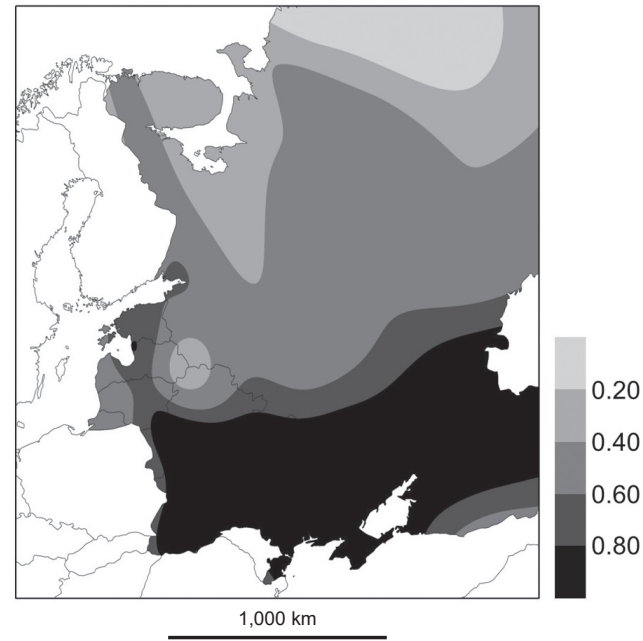

Fig. 2 - The value of the $95^{\text {th }}$ annual percentile of $T_{\max }\left({ }^{\circ} \mathrm{C} ; \mathrm{a}\right)$, mean $\mathrm{T}_{\max }$ $\left({ }^{\circ} \mathrm{C}\right.$ ) in the summer (June-August; b), changes in the mean summer $\mathrm{T}_{\max }$ in ${ }^{\circ} \mathrm{C} / 10$ years $(\mathrm{c})$, for the period 1973-2010 
Aleksandrov-Gaj

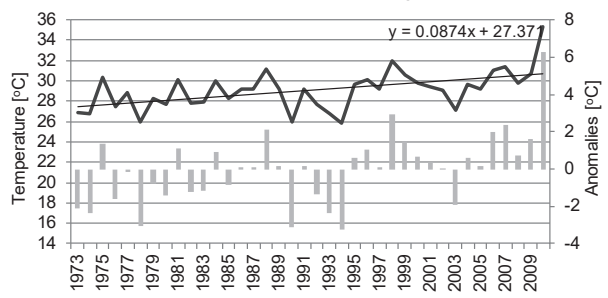

Donetsk

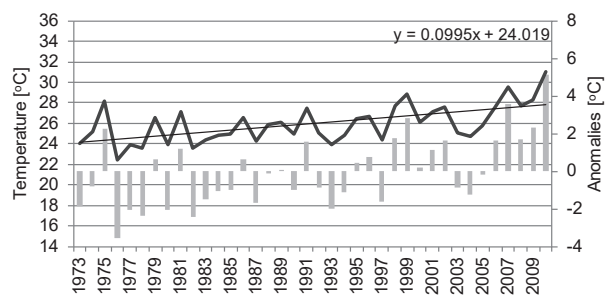

Penza

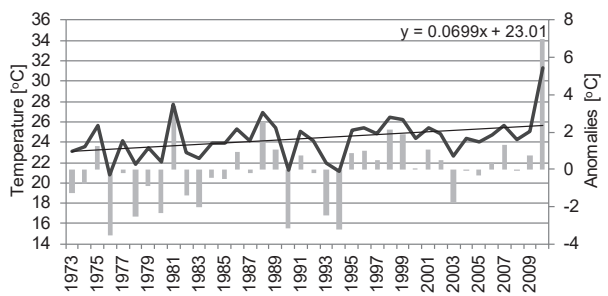

Arkhangelsk

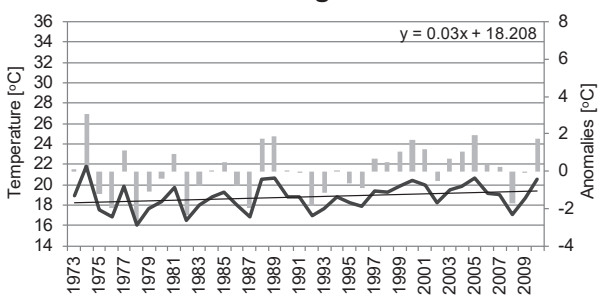

Pechora

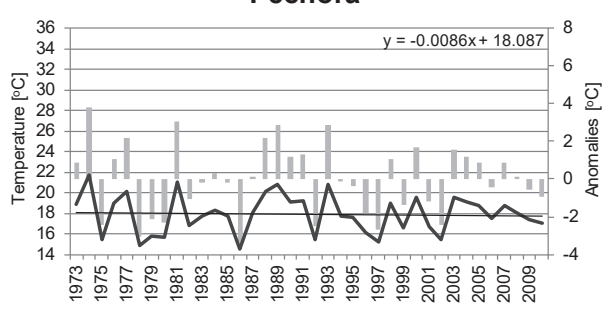

Simferopol

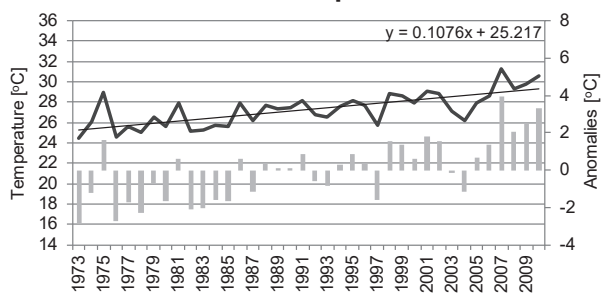

Fig. 3 - Mean summer $\mathrm{T}_{\max }\left({ }^{\circ} \mathrm{C}\right)$ (black line) with the trend line and regression equation, and Tmax anomalies from the mean $T_{\max }\left({ }^{\circ} \mathrm{C}\right)$ in the 1973-2010 period (grey columns) at selected stations

$\mathrm{T}_{\max }\left(-0.09^{\circ} \mathrm{C} / 10\right.$ years $)$ recorded, but still that was statistically insignificant. The increase was considerably influenced by changes in the $\mathrm{T}_{\max }$ in the first decade of the $21^{\text {st }}$ century when the $T_{\max }$ generally exceeded the average for the 1973-2010 period. The thermally extreme summer of 2010 had a significant influence on the observed changes in $\mathrm{T}_{\max }$ in the analysed multi-year period, with $57 \%$ of stations recording the highest positive $\mathrm{T}_{\max }$ anomalies in the entire 38 -year study period. Additionally, $33 \%$ of stations saw anomalies of $\geq 5^{\circ} \mathrm{C}$ in that year. In the analysed period, the deviation range fluctuated from $-3.6^{\circ} \mathrm{C}$ in Donetsk (1976) to $7.0^{\circ} \mathrm{C}$ in Penza (2010). 


\subsection{Hot days}

In Eastern Europe, the observed increase in $\mathrm{T}_{\max }$ translated into an increase in the number of hot days and, consequently, into an increase in the frequency of occurrence of heat waves. In all the stations there were statistically significant correlations between the mean $\mathrm{T}_{\max }$ in summer and the number of hot days recorded, with the correlation coefficient fluctuating around 0.81-0.96.

In $70 \%$ of the stations, the highest number of hot days was recorded in the summer of 2010. In this season, their number ranged from 19 (Pechora) to 67 (Kharkiv, Kursk). Only in Pechora was the highest number of hot days in the season not recorded in the first decade of the $21^{\text {st }}$ century; that took place in 1974 instead (34 days). The lowest number of hot days was recorded mainly in the 70s and the 90 s of the $20^{\text {th }}$ century. In most of the stations, the $1978,1976,1993$ and 1980 seasons recorded the lowest number of hot days. Only in Saint Petersburg did the summer with the lowest number of hot days occur in the first decade of the $21^{\text {st }}$ century (2008, only 3 days).

In the analysed period, in Eastern Europe, the average increase in number of hot days was 4.5 days per 10 years and this was statistically significant. The highest increase in number of hot days was recorded in Simferopol (8.4 days/10 years) and Donetsk ( 8.0 days/10 years), while the lowest was in Pechora (0.6 days/10 years;

Kharkiv

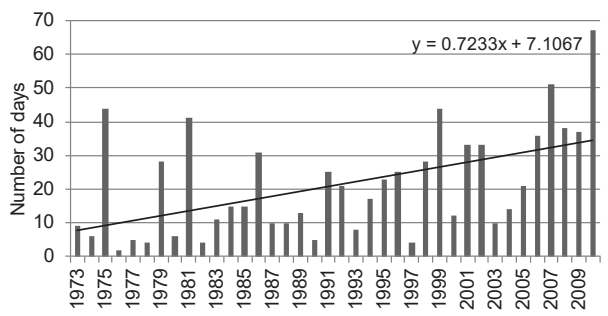

Saint Petersburg

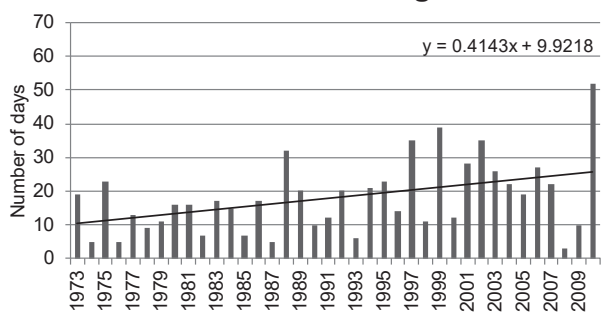

Pechora

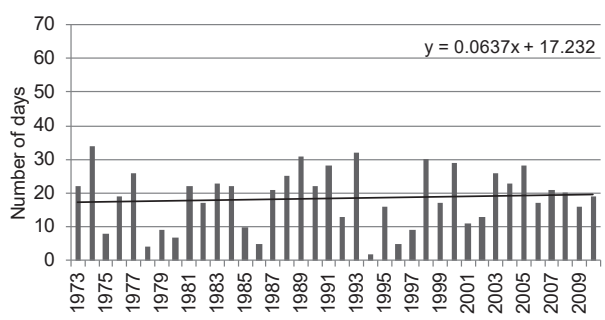

Simferopol

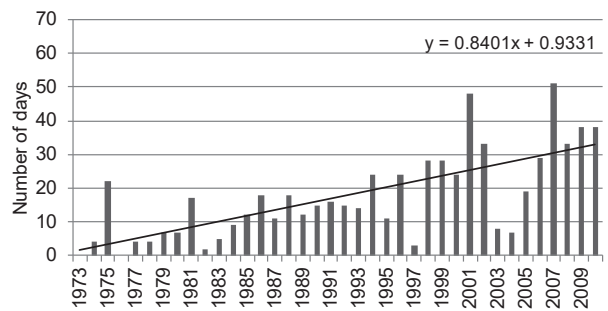

Fig. 4 - Multi-year series of the annual number of hot days, with trend line and regression equation at selected stations 
Fig. 4). In $79 \%$ of the stations, the recorded changes were statistically significant, at a level of $\mathrm{p} \leq 0.05$.

The highest number of hot days was recorded in July and August and these, on average, constitute $40 \%$ and $27 \%$, respectively, of all hot days. In most of the stations these days were recorded in the period from April to September or October (in 8 stations). One exception was the station in Sochi, where two hot days were recorded - a single day each in March (24.03.2008) and November (15.11.1973); therefore, the potential period of the occurrence of hot days was 237 days and was the longest within the analysed area. On the other hand, the shortest potential period of the occurrence of hot days was specific to the station in Volgograd (only 110 days), while in most of the stations its length fluctuated around 130-150 days.

\subsection{Heat waves}

In Eastern Europe between 1973 and 2010, the total number of heat waves ranged from 24 in Kaliningrad to 55 in Kharkiv, and their duration was, respectively, 157 and 414 days. In approximately $37 \%$ of the stations, the lowest number of heat waves was recorded between 1973 and 1980, and their number fluctuated between 0 (Lviv, Ufa) and 11 (Arkhangelsk, Petrozavodsk). On the other hand, in $85 \%$ of the stations, the highest number of heat waves occurred in the first decade of the $21^{\text {st }}$ century, when their number fluctuated from 7 (Murmansk) to 25 (Kharkiv; Fig. 5). In the above-mentioned decade, in $76 \%$ of the stations, the total duration of heat waves exceeded 100 days, while in the 80 s and the 90 s of the $20^{\text {th }}$ century, the total time of 100 days was only recorded in four stations.

In $76 \%$ of the stations the most often recorded waves were those lasting 5 days (minimum length), and in $21 \%$ of the stations they were 6-day heat waves. In Daugavpils, the most often recorded were heat waves lasting 7 days. On the other hand, only in Murmansk were there no heat waves of more than 10 days recorded in the analysed period. The longest heat wave was recorded in Moscow in 2010, lasting as many as 45 days, from 5 July to 18 August.

In the analysed period, the heat waves occurred from April to September; however, they were most often recorded in July (on average, $47 \%$ of all heat waves). Only in Kursk was the highest number of heat waves observed in June. In most of the stations, the first heat wave was most often recorded in the second half of May, and the last in the second half of August. The start of the earliest heat waves at individual stations was observed between April 30 in Brest and June 21 in Sochi. On the other hand, the last day of the latest heat waves occurred between August 10 in Pechora and September 21 in Sochi. Based on the start dates of the earliest heat waves and the end dates of the latest, their potential period of occurrence was determined, and ranged from 69 days in Simferapol (June 20 to August 27) to 
125 days in Brest and Kursk (April 30 to September 1 and May 8 to September 9, respectively). The longest potential period was found in the west of the study area, and lasted $>100$ days. Meanwhile, for all of Eastern Europe under study, the potential period of occurrence of heat waves was 145 days (April 30 to September 21; Fig. 6).

The mean $\mathrm{T}_{\max }$ during the analysed heat waves was $30^{\circ} \mathrm{C}$, while mean $\mathrm{T}_{\min }$ was $16.5^{\circ} \mathrm{C}$. The highest mean $\mathrm{T}_{\max }$ was observed during heat waves in Aleksandrov-Gaj (21.07-14.08.2010) and was $39.6^{\circ} \mathrm{C}$, while the highest mean $\mathrm{T}_{\min }$ was in Volgograd (9.07-13.07.2010), and was $23.8^{\circ} \mathrm{C}$. In the analysed period, in $48.5 \%$ of the stations there was a statistically significant increase in $\mathrm{T}_{\max }$ during heat waves, while in $33.3 \%$ of those there was a statistically significant increase in $\mathrm{T}_{\min }$. Only in Murmansk was there a statistically significant decrease in $\mathrm{T}_{\min }$ observed during heat waves.

\subsection{Atmospheric circulation and heat waves}

Between 1973 and 2010, the highest mean summertime (June-August) sea-level pressure in the Euro-Atlantic sector occurred in the area of the Azores Islands $(>1,024 \mathrm{hPa})$. The pressure drop occurred in a northerly direction, and the low pressure centre was located in the southwest of Iceland ( $<1,009 \mathrm{hPa}$; Fig. 7a). Between the mentioned pressure centres over the ocean, a considerable horizontal pressure gradient was observed, and a far less considerable one was found over the continent. In the summer season, the averaged $500 \mathrm{hPa}$ geopotential height was inclined towards the northwest. The maximum height $\mathrm{Z} 500 \mathrm{hPa}$ was recorded over the Mediterranean Sea (>5,880 gpm), and the minimum was found over the northern Atlantic $(<5,500 \mathrm{gpm})$. The air temperature on the $850 \mathrm{hPa}$ constant-pressure surface decreased from the south $\left(>20^{\circ} \mathrm{C}\right)$ to the northwest $\left(<0^{\circ} \mathrm{C}\right.$; Fig. $\left.7 \mathrm{~b}\right)$. The aforementioned pressure system caused the west circulation - typical for Europe both in the middle and bottom troposphere.

The occurrence of heat waves in Eastern Europe in the analysed years was, on average, connected with a ridge of high pressure lying across Europe, within which a high-pressure area formed with its centre over Russia (>1,016 hPa; Fig. 8a). The contour lines of $500 \mathrm{hPa}$ geopotential height over the eastern part of the continent bent northward creating a clear elevation over the analysed area, which confirms the presence of warm air masses. This is connected with the relationship between temperature and air density and the resulting pressure change with height in different thermal conditions: warm air masses are lower in density than cool masses, and therefore the drop in pressure as one ascends is slower. During heat waves, the pressure over the analyzed area was higher than the average summer season pressure, which was confirmed on the sketches of maps of SLP anomalies, and 
Fig. 5 -The total number of heat waves (left column) and the total duration of heat waves (right column), for 1973-2010

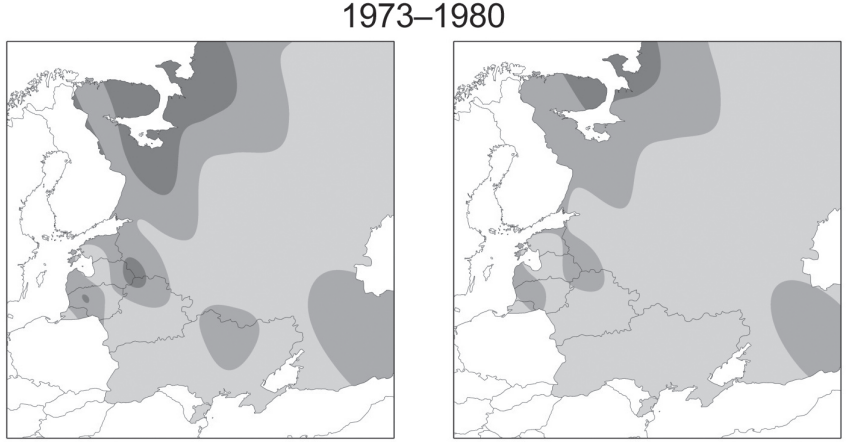

1981-1990
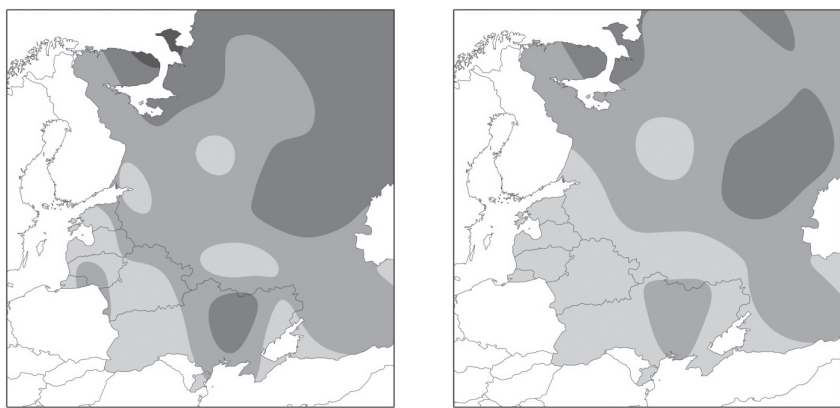

1991-2000
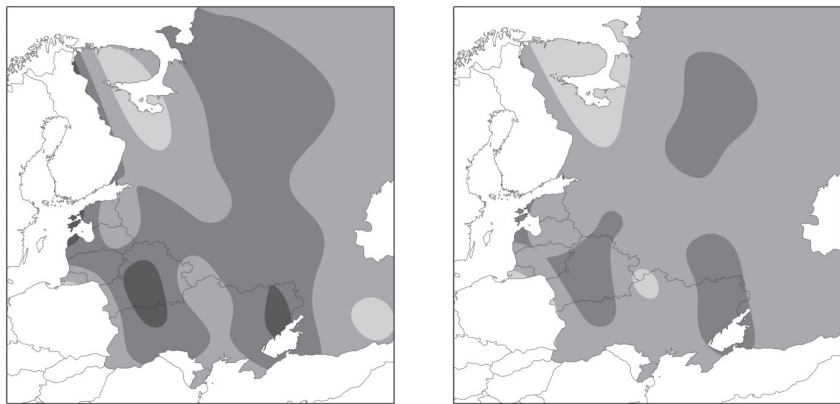

\section{1-2010}
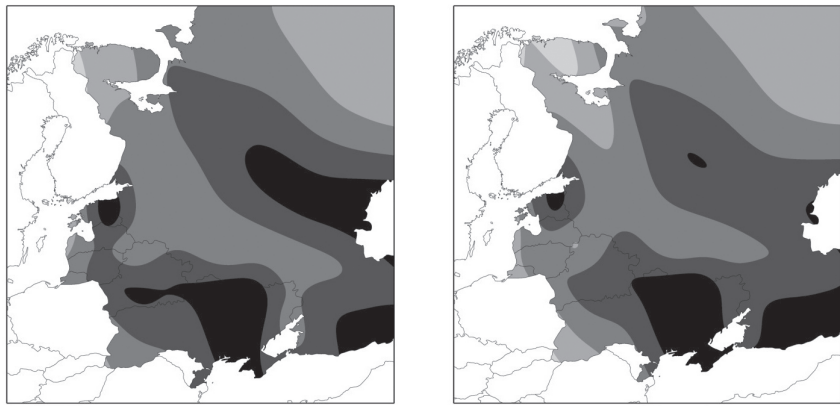

$1,000 \mathrm{~km}$

20

$\begin{array}{llll}45 & 90 & 135 & 180\end{array}$ 
(a)

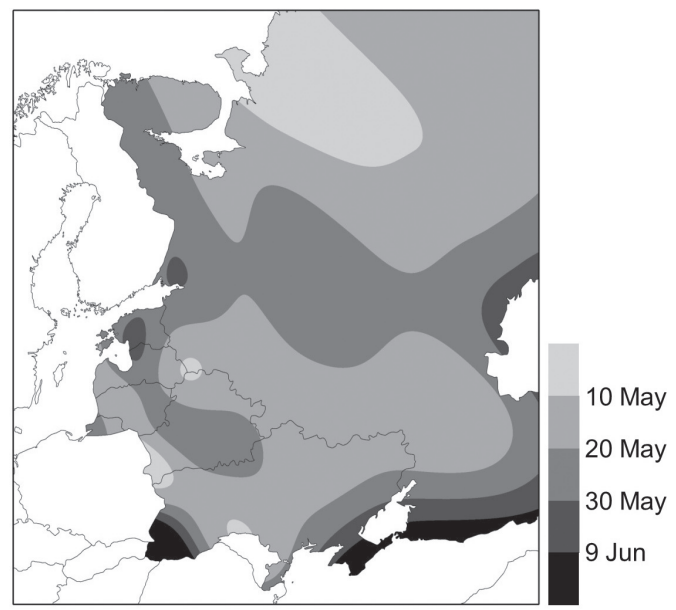

(b)

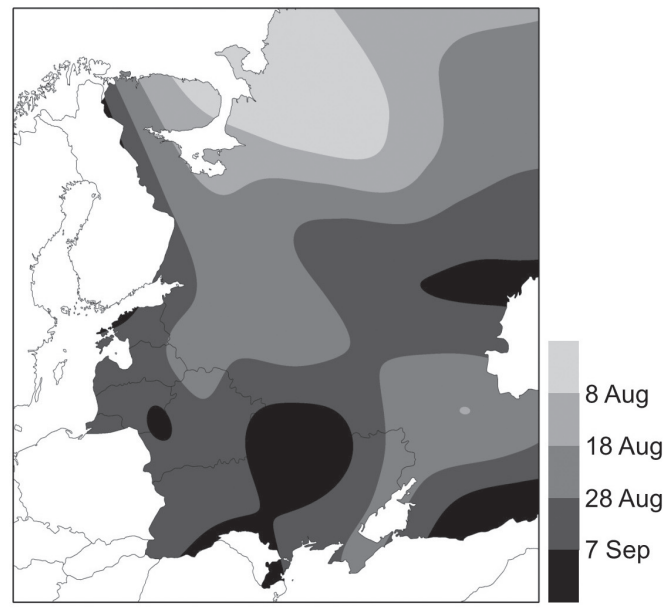

(c)

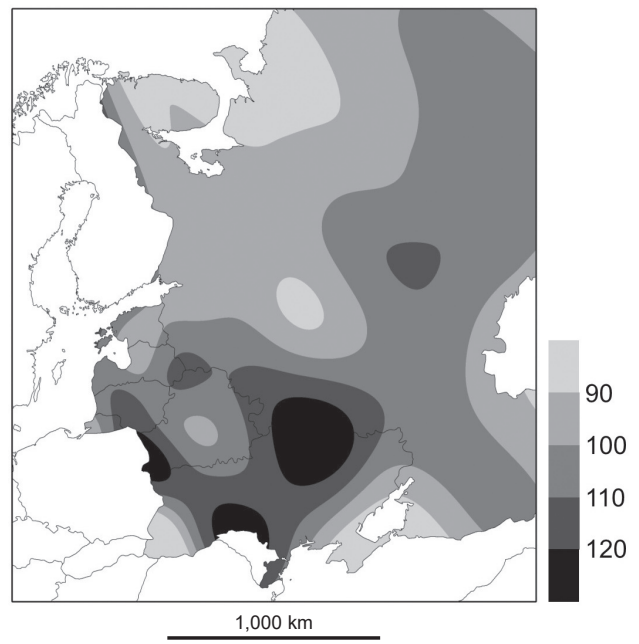

Fig. 6 - Start date of earliest heat wave (a), end date of latest heat wave (b) and duration of potential period of heat wave occurrence $(c)$ 
(a)

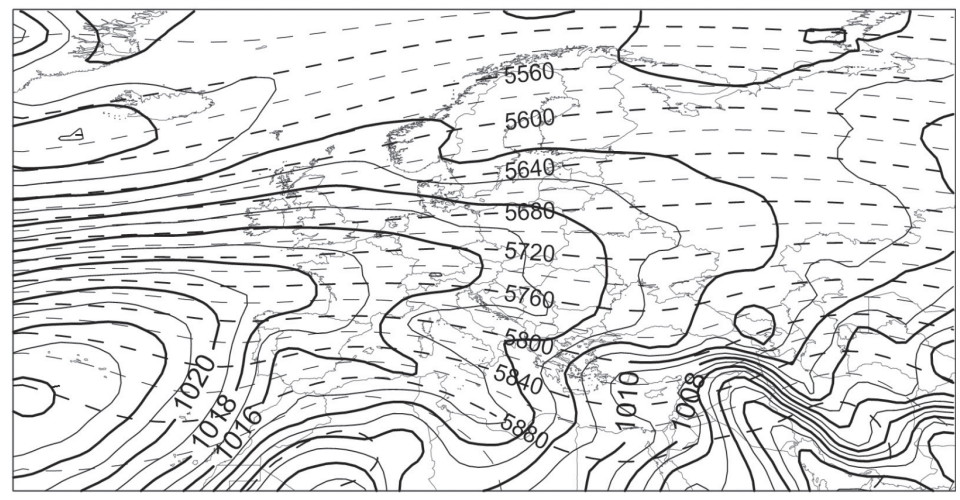

(b)

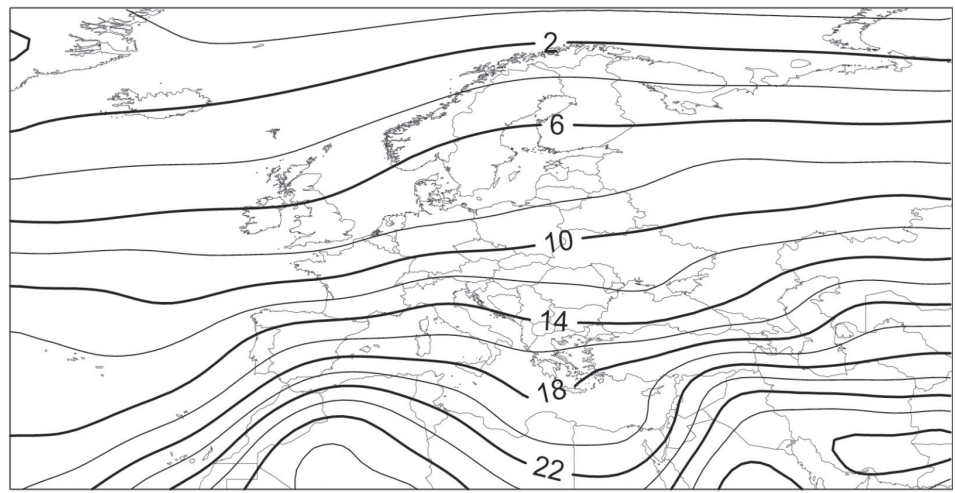

$3,000 \mathrm{~km}$

Fig. 7 - Mean summer (June-August) SLP (hPa; solid lines) and Z500 hPa (gpm; dashed lines; a) and $\mathrm{T} 850\left({ }^{\circ} \mathrm{C} ; \mathrm{b}\right)$

ranged from 0 to $>4 \mathrm{hPa}$. On the other hand, $\mathrm{Z} 500 \mathrm{hPa}$ anomalies over the analysed area fluctuated between 15 and $>90 \mathrm{~m}$ (Fig. 8b). The occurrence of heat waves was also connected with $\mathrm{T} 850$ positive anomalies (in the centre these were $>4^{\circ} \mathrm{C}$; Fig. $8 \mathrm{c}$ ). The system described above provided an inflow of solar radiation, with little or zero cloud cover, which is particular to anticyclonic weather. Additionally, the system caused an inflow of warm and dry continental air masses in the bottom troposphere from the eastern sector. On the other hand, advection of tropical air masses from the southern sector occurred in higher layers of the troposphere.

Hot days constituting heat waves were grouped according to pressure at sea level, and on this basis divided into two circulation types. The dominant circulation type (412 days) causing the occurrence of this type of day was type 1 (T1), with a high centred over northwestern Russia (>1,016 hPa), where SLP was $4 \mathrm{hPa}$ higher than the summer average for the analysed century. Only in the southeastern part of the analysed area was SLP close to the century values for the days concerned. On 
(a)

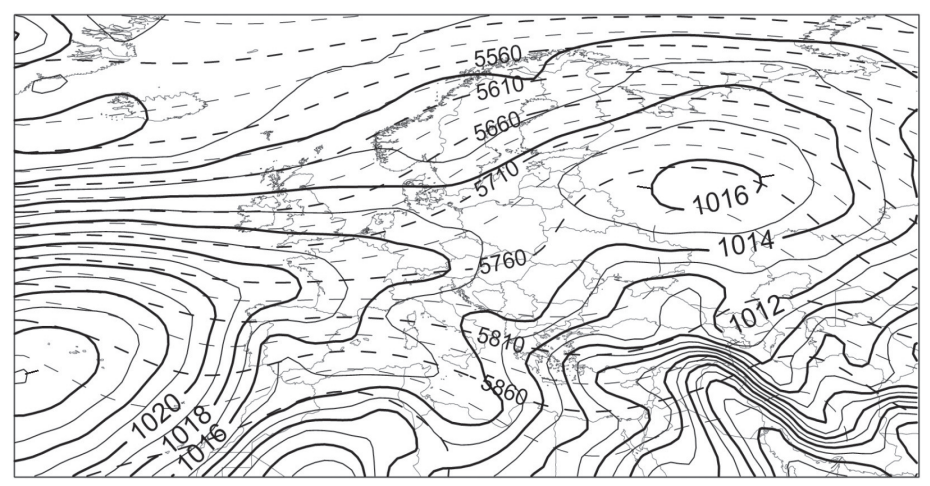

(b)

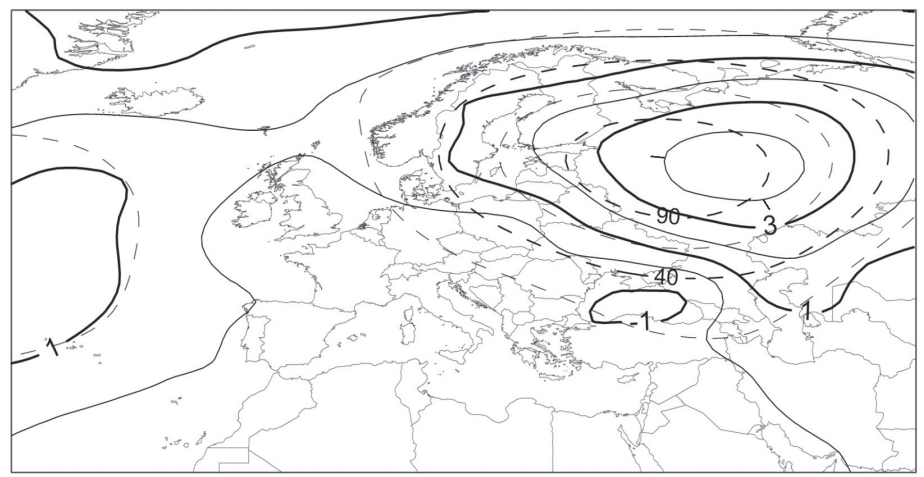

(c)

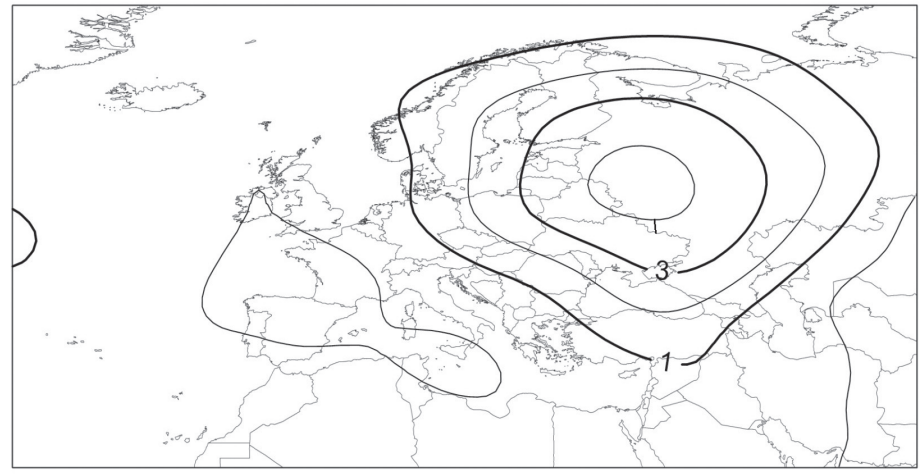

$3,000 \mathrm{~km}$

Fig. 8 - Mean SLP (hPa; solid lines) and Z500 hPa (gpm; dashed lines; a), SLP (hPa; solid lines) and $\mathrm{Z} 500 \mathrm{hPa}$ anomalies ( $\mathrm{m}$; dashed lines; b) and anomalies of $\mathrm{T} 850\left({ }^{\circ} \mathrm{C} ; \mathrm{c}\right)$ for heat wave days

the other hand, 213 hot days were classified as type 2 (T2), during which, Europe was under the influence of a large wedge of high pressure. Hanging over northeastern Russia was a local high pressure centre of $>1,016 \mathrm{hPa}$. In this type, as with type 1, positive SLP anomalies were observed ( $>4 \mathrm{hPa}$ in the centre), although they 
(a)

\section{Type 1}

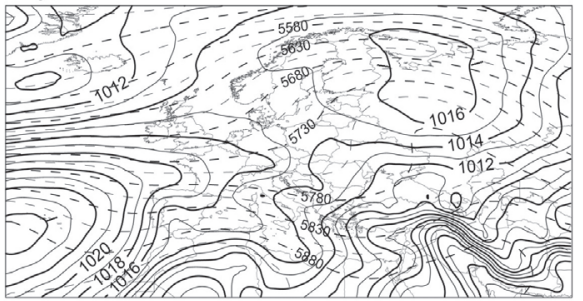

(b)

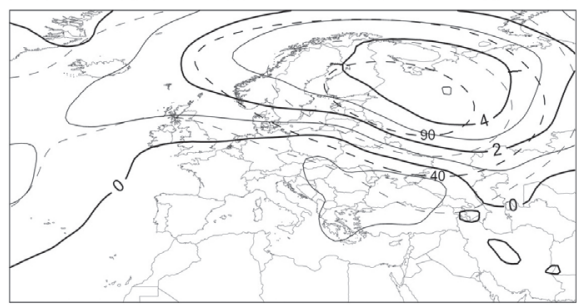

(c)

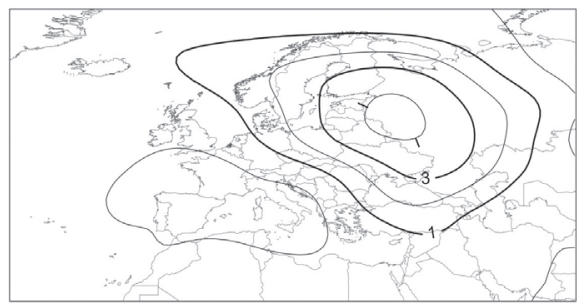

Type 2
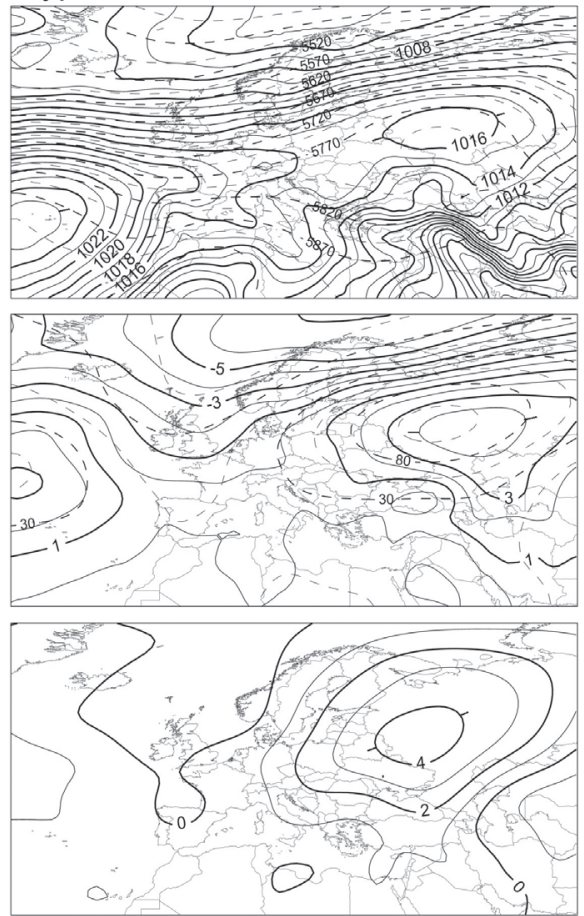

$3,000 \mathrm{~km}$

Fig. 9 - Mean SLP (hPa; solid lines) and Z500 hPa (gpm; dashed lines; a), SLP (hPa; solid lines) and $\mathrm{Z} 500 \mathrm{hPa}$ anomalies ( $\mathrm{m}$; dashed lines; b) and anomalies of $\mathrm{T} 850\left({ }^{\circ} \mathrm{C} ; \mathrm{c}\right)$ for the synoptic type 1 and 2 causing heat waves

were more southerly than those of type 1 . The isohypses of $500 \mathrm{hPa}$ geopotential height over Eastern Europe bent towards the northeast for type 1 and towards the north for type 2, forming a clear upward slope over the analysed area. Positive anomalies in both $\mathrm{Z} 500 \mathrm{hPa}$ and $\mathrm{T} 850$ indicate the presence of warm air masses in this part of the continent. For type 2, the greater part of the analysed area was within the range of the higher T850 anomalies (Fig. 9).

\subsection{The heat wave of 2010 in Moscow}

The heat wave recorded from 5 July to 18 August 2010 in Moscow was the longest in Eastern Europe in the analysed period. During that heat wave, the mean $\mathrm{T}_{\max }$ was $33^{\circ} \mathrm{C}$, while the mean $\mathrm{T}_{\min }$ was $20^{\circ} \mathrm{C}$, and one can distinguish two periods of extremely high temperature, namely, from 22 to 29 July and from 2 to 11 


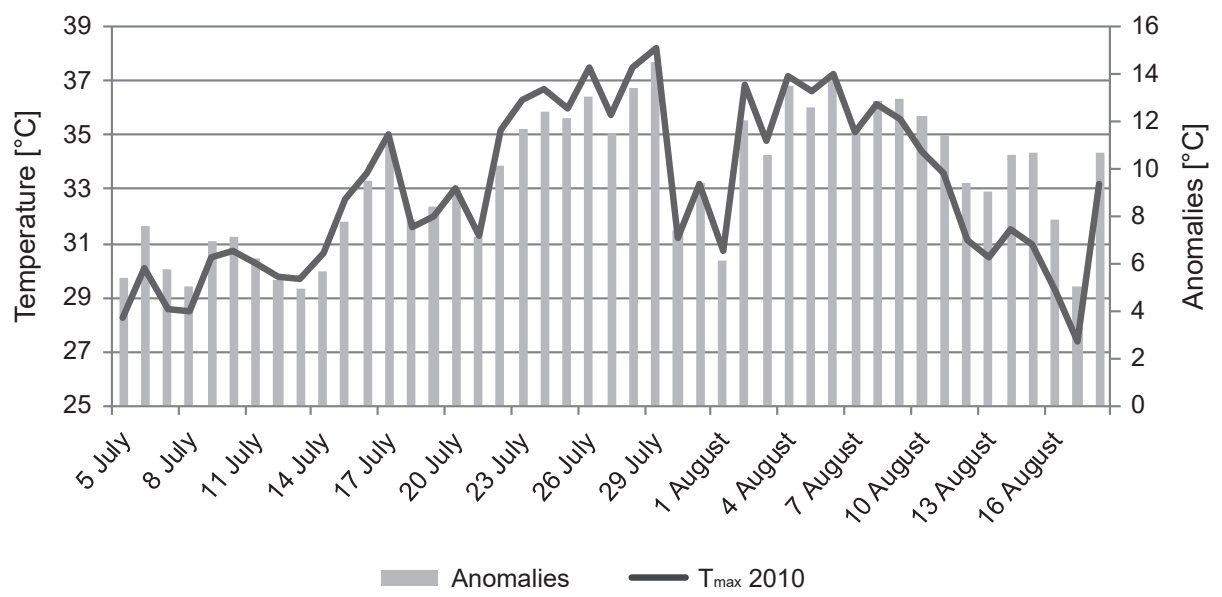

Fig. 10 - The $T_{\max }\left({ }^{\circ} \mathrm{C}\right)$ in 2010 (black line) and $T_{\max }$ anomalies $\left({ }^{\circ} \mathrm{C}\right)$ from the mean $T_{\max }$ in 1973-2010 period (grey columns) in Moscow

August. These periods were separated with 3 days of colder weather (but with the $\mathrm{T}_{\max }>30^{\circ} \mathrm{C}$ ) caused by the passage of a cold front. The highest $\mathrm{T}_{\max }$ was recorded on 29 July $\left(38.2^{\circ} \mathrm{C}\right)$, and it was higher by $14.5^{\circ} \mathrm{C}$ than the mean for that day in the analysed period (Fig. 10).

The occurrence of the above-mentioned heat wave was connected with the presence of a centre of high pressure over Eastern Europe (with its centre > 1,018 hPa; Fig. 11a). In the analysed period, SLP in the centre was $>6 \mathrm{hPa}$ higher than its mean summer value. The contour lines of geopotential height of $500 \mathrm{hPa}$ clearly bent northward over the eastern part of the continent, indicating the presence of warm air masses. $\mathrm{Z} 500 \mathrm{hPa}$ anomalies exceeded $180 \mathrm{~m}$ in the centre (Fig. 11b). In the discussed period, positive anomalies of air temperature on the $850 \mathrm{hPa}$ pressure surface were also observed, and those were $>9^{\circ} \mathrm{C}$ over western Russia (Fig. 11C). The high temperature was provided by high-pressure weather causing an intensive inflow of solar radiation and advection of warm and dry continental air masses.

\section{Discussion}

The increase in $T_{\max }$ shown in the article was analogous to the results obtained for Central Europe, which were $0.52^{\circ} \mathrm{C} / 10$ years (Tomczyk, Bednorz 2016), and for Northern Europe, which were $0.38^{\circ} \mathrm{C} / 10$ years (Tomczyk, Piotrowski, Bednorz 2016). Similarly, in the research study of Twardosz and Kossowska-Cezak (2015) it was shown that the summer of 1974 in Arkhangelsk stood out against the period and was considered an extremely hot summer. The increase in frequency 
(a)

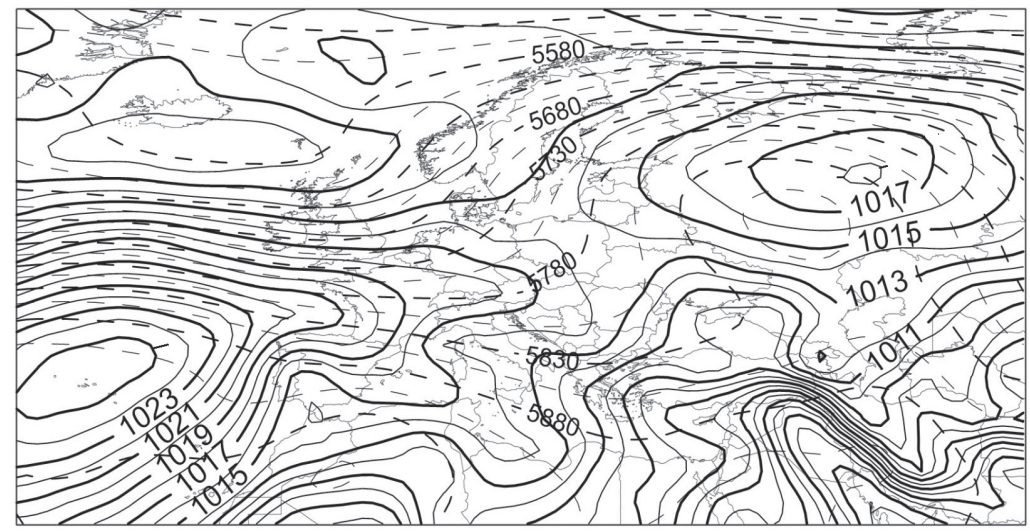

(b)

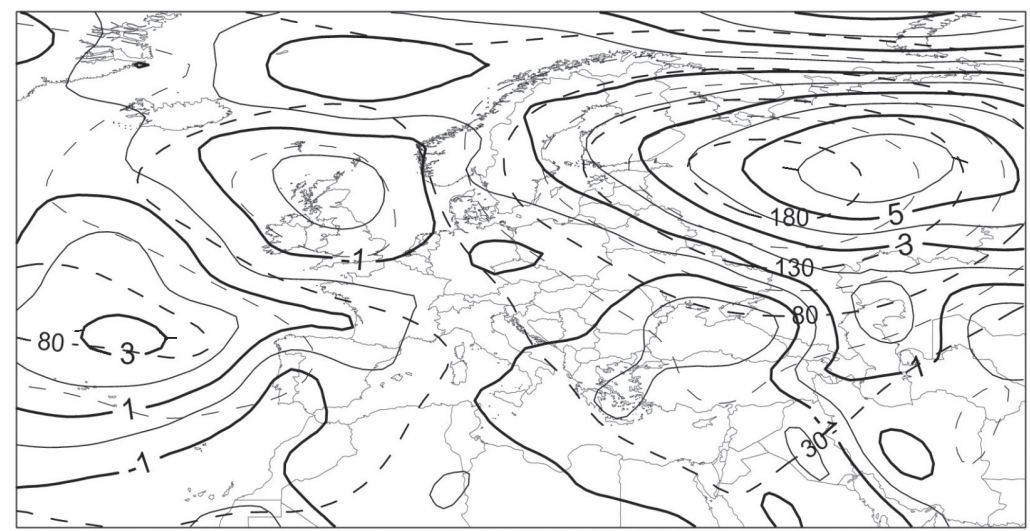

(c)

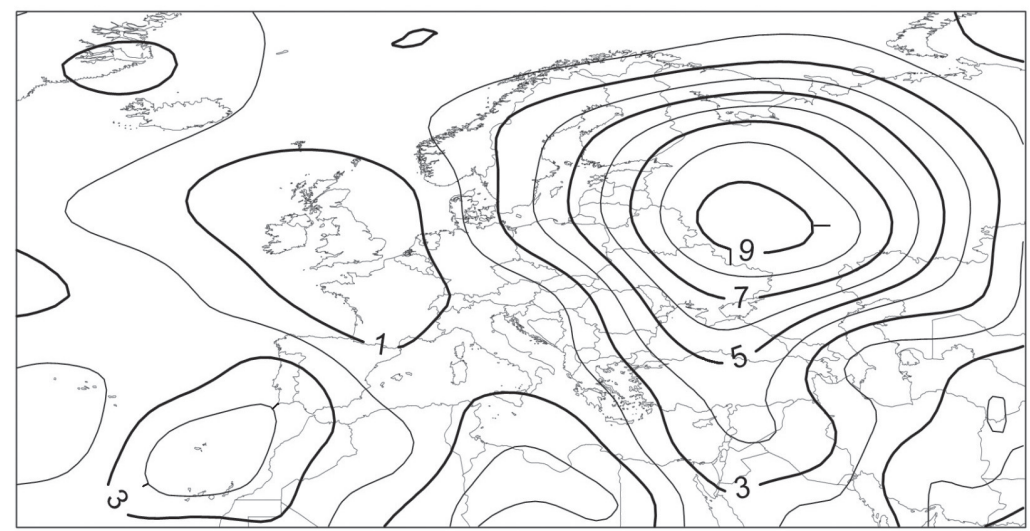

$3,000 \mathrm{~km}$

Fig. 11 - Mean SLP (hPa; solid lines) and Z500 hPa (gpm; dashed lines; a), SLP (hPa; solid lines) and $\mathrm{Z} 500 \mathrm{hPa}$ anomalies ( $\mathrm{m}$; dashed lines; $\mathrm{b})$, and the T850 anomalies $\left({ }^{\circ} \mathrm{C} ; \mathrm{c}\right)$ for the heat waves of 2010 
of extremely hot summer months and seasons in Central and Eastern Europe is a sign of warming, with their highest number observed in the first decade of the $21^{\text {st }}$ century (Twardosz, Kossowska-Cezak 2013).

The observed increase in $\mathrm{T}_{\max }$ in summer caused the increase in the frequency of the occurrence of heat waves and hot days not only in the analysed area but also, among others, in Czechia (Kyselý 2010), Greece (Founda, Giannakopoulos 2009), Lithuania (Kažys et al. 2011), Latvia (Avotniece, Kḷaviṇš, Rodinovs 2010; Avotniece et al. 2012), Spitsbergen (Bednorz, Kolendowicz 2013; Tomczyk, Bednorz 2014b), Turkey (Erlat, Türkeş 2013), and Ukraine (Shevchenko et al. 2014), as well as outside Europe, e.g. in China (Ding, Qian, Yan 2010), India (Pai, Nair, Ramanathan 2013), Mongolia (Batima et al. 2005) and USA (Peterson et al. 2013). On the other hand, research studies concerning circulation conditions causing the occurrence of heat waves in many regions of Europe showed, similarly to this article, that these occurred most of all with anticyclonic weather conditions, which is conducive to strong insolation (Black et al. 2004; Fink et al. 2004; Rebetez, Dupont, Giroud 2006; Founda, Giannakopoulos 2009; Unkašević, Tošić 2015).

The conducted research showed that the longest heat wave in the analysed period was that recorded in Moscow in 2010, which was connected with the presence of a high-pressure system over the analysed area; that is, a blocking pattern. The obtained results are consistent with the previous research studies focusing solely on the analysis of the aforementioned heat wave (Lau, Kim 2012; Matsueda 2011; Galarneau et al. 2012; Schneidereit et al. 2012). The consequence of the occurrence of that heat wave was, among others, an increase in mortality caused by biometeorological conditions affecting human body systems. It is estimated that the increase in overall mortality was approximately 11,000 individuals above the expected value, and mainly affected people over 65 years old (Shaposhnikov et al. 2014). Revich et al. (2015) analysed the impact of heat waves on mortality in selected cities of southern Russia and showed that mortality was nearly twice as high in the 65+ age group as in the 30-64 age group. The increase in fatalities related to adverse weather conditions such as high air temperatures and heat waves has also been shown in previous studies relating to, among others, Europe and USA (Kalkstein 1993; Kalkstein, Greene 1997; Poumadere 2005; Bobvos, Fazekas, Páldy 2015).

\section{Conclusions}

Between 1973 and 2010, in Eastern Europe, an increase was observed in summer $\mathrm{T}_{\max }$, and the averaged value for the whole area was $0.67^{\circ} \mathrm{C} / 10$ years. The above-mentioned increase was considerably influenced by changes of $\mathrm{T}_{\max }$ in the first decade of the $21^{\text {st }}$ century when $\mathrm{T}_{\max }$ generally exceeded the norm for the 
1973-2010 period. In $84.8 \%$ of the stations, the highest mean $\mathrm{T}_{\max }$ in summer was observed between 2001 and 2010, while only in and Pechora was it observed in the 70 s of the $20^{\text {th }}$ century (in 1974).

The observed increase in $\mathrm{T}_{\max }$ translated into an increase in the number of hot days and, consequently, an increase in the frequency of heat wave occurrence. In the analysed period, the rate of change in number of hot days was 4.5 days/10 years. In the discussed stations, apart from the station in Pechora, the season with the greatest number of hot days occurred in the first decade of the $21^{\text {st }}$ century, and in $70 \%$ of the stations it happened in 2010. On the other hand, in Pechora, this kind of season was observed in 1974.

The occurrence of the analysed heat waves in Eastern Europe was on average related to a centre of high pressure settling over the above-mentioned area, providing strong insolation with cloudlessness or little cloud cover. Additionally, those conditions were supported by the advection of dry and continental air masses. The detailed analysis of pressure conditions showed that the occurrence of heat waves may be associated with two types of circulation. In the analysed years, the type with high pressure with its centre located in Northwest Russia dominated. On the other hand, in the other type, there was a ridge of high pressure lying over Europe, within which a local high-pressure area was formed in southwestern Russia. During the heat waves, there were positive anomalies observed over the analysed area, both of SLP, Z500 hPa and T850.

\section{References}

ACAR DENIZA, Z., GÖNENÇGILB, B. (2015): Trends of summer daily maximum temperature extremes in Turkey. Physical Geography, 36, 4, 261-281.

AVOTNIECE, Z., RODINOV, V., LIZUMA, L., BRIEDE, A., KL̦AVIN̦Š, M. (2010): Trends in the frequency of extreme climate events in Latvia. Baltica, 23, 2, 135-148.

AVOTNIECE, Z., KL̦AVIN̦Š, M., RODINOVS, V. (2012): Changes of Extreme Climate Events in Latvia. Environmental and Climate Technologies. doi: 10.2478/v10145-012-0010-1.

BARRIOPEDRO, D., FISCHER, E.M., LUTERBACHER, J., TRIGO, R.M., GARCÍA-HERRERA, R. (2011): The hot summer of 2010: redrawing the temperature record map of Europe. Science, 332, 220-224.

BATIMA, P., NATSAGDORJ, L., GOMBOLUUDEV, P., ERDENETSETSEG, B. (2005): Observed climate change in Mongolia. AIACC Working Paper, 13, 4-25.

BEDNORZ, E., KOLENDOWICZ, L. (2013): Summer mean daily air temperature extremes in Central Spitsbergen. Theoretical and Applied Climatology, 113, 471-479.

BEDNORZ, E., WIBIG, J. (2015): Spatial distribution and synoptic conditions of snow accumulation and snow ablation in the West Siberian Plain. Quaestiones Geographicae, 34, 3, 5-15.

BIELEC-BĄKOWSKA, Z. (2010): Strong highs over Europe in $20^{\text {th }}$ century. In: Kolendowicz, L. (ed.): Klimat Polski na tle klimatu Europy, Warunki cyrkulacyjne i radiacyjne, 23-37. (In Polish.) 
BIELEC-BĄKOWSKA, Z. (2014): Silne wyże nad Europą 1951-2010 (Strong anticyclones over Europe 1951-2010). Wydawnictwo Uniwersytetu Śląskiego, Katowice.

BLACK, E., BLACKBURN, M., HARRISON, G., HOSKINS, B., METHVEN, J. (2004): Factors contributing to the summer 2003 European heatwave. Weather, 59, 217-223.

BOBVOS, J., FAZEKAS, B., PÁLDY, A. (2015): Assessment of heat-related mortality in Budapest from 2000 to 2010 by different indicators. Időjárás, 119, 2, 143-158.

DING, T., QIAN, W.H., YAN, Z.W. (2010): Changes of hot days and heat waves in China during 1961-2007. International Journal of Climatology, 30, 142-146.

DOLE, R., HOERLING, M., PERLWITZ, J., EISCHEID, J., PEGION, P., ZHANG, T., QUAN, TAIYI, X.U., MURRAY, D. (2011): Was there a basis for anticipating the 2010 Russian heat wave? Geophysical Research Letters, 38, L06804. doi: 10.1029/2010GL046582.

ERLAT, E., TÜRKEŞ, M. (2013): Observed changes and trends in numbers of summer and tropical days, and the 2010 hot summer in Turkey. International Journal of Climatology, 33, 1898-1908.

ESTEBAN, P., JONES, P.D., MARTIN-VIDE, J., MASES, M. (2005): Atmospheric circulation patterns related to heavy snowfall days in Andorra, Pyrenees. International Journal of Climatology, 25, 319-329.

FINK, A., BRÜCHER, T., KRÜGER, A., LECKEBUSCH, G., PINTO, J., ULBRICH, U. (2004): The 2003 European summer heatwaves and drought-synoptic diagnosis and impacts. Weather, 59, 209-216.

FRICH, P., ALEXANDER, L.V., DELLA-MARTA, P., GLEASON, B., HAYLOCK, M., KLEIN TANK, A.M.G., PETERSON, T. (2002): Observed coherent changes in climatic extremes during $2^{\text {nd }}$ half of the $20^{\text {th }}$ century. Climate Research, 19, 193-212.

FOUNDA, D., GIANNAKOPOULOS, C. (2009): The exceptionally hot summer of 2007 in Athens, Greece-a typical summer in the future climate? Global and Planetary Change, 67, 3-4, 227-236.

GALARNEAU, T.J., HAMILL, T.M., DOLE, R.M., PERLWITZ, J. (2012): A multiscale analysis of the extreme weather events over Western Russia and Northern Pakistan during July 2010. Monthly Weather Review, 14, 1639-1664.

GLICKMANN, T.D., ed. (2000): Glossary of Meteorology. American Meteorological Society, Boston.

GRUMM, R.H. (2011): The Central European and Russian heat event of July-August 2010. Bulletin of the American Meteorological Society, 92, 1285-1296.

IPCC (2001): Climate change: The physical science basis. Contribution of Working Group I to the Third Assessment Report of the Intergovernmental Panel in Climate Change, Cambridge University Press, Cambridge.

IPCC (2007): Climate change: The physical science basis. Contribution of Working Group I to the Fourth Assessment Report of the Intergovernmental Panel in Climate Change, Cambridge University Press, Cambridge.

IPCC (2013): Climate change: The physical science basis. Contribution of Working Group I to the Fifth Assessment Report of the Intergovernmental Panel in Climate Change, Cambridge University Press, Cambridge.

KALKSTEIN, L.S. (1993): Health and climate change: direct impacts in cities. Lancet, 342, 1397-1399.

KALKSTEIN, L.S., GREENE, J.S. (1997): An evaluation of climate/mortality relationships in large U.S. cities and the possible impacts of a climate change. Environ Health Perspect, 105, 84-93. 
KALNAY, E., KANAMISTU, M., KISTLER, R., COLLINS, W., DEAVEN, D., GANDIN, L., IREDELL, M., SAHA, S., WHITE, G., WOOLLEN, J., ZHU, Y., LEETMAA, A., REYNOLDS, R., CHELLIAH, M., EBISUZAKI, W., HIGGINS, W., JANOWIAK, J., MO, K.C., ROPELEWSKI, C., WANG, J., JENNE, R., JOSEPH, D. (1996): The NMC/NCAR 40-Year Reanalysis Project. Bulletin of the American Meteorological Society, 77, 437-471.

KAŽYS, J., STANKŪNAVIČIUS, G., RIMKUS, E., BUKANTIS, A., VALIUKAS, D. (2011): Longrange alternation of extreme high day and night temperatures in Lithuania. Baltica, 24, 2, 71-82.

KOFFI, B., KOFFI, E. (2008): Heat waves across Europe by the end of the $21^{\text {st }}$ century: multiregional climate simulations. Climate Research, 36, 153-168.

KOZŁOWSKA-SZCZĘSNA, T., KRAWCZYK, B., KUCHCIK, M. (2004): Wpływ środowiska atmosferycznego na zdrowie i samopoczucie człowieka (The influence of atmospheric environment on the human health and well being). IGiPZ im. Stanisława Leszczyckiego PAN, Warszawa.

KUCHCIK, M., DEGÓRSKI, M. (2009): Heat- and cold-related mortality in the north-east of Poland as an example of the socio-economic effects of extreme hydrometeorological events in the Polish Lowland. Geographia Polonica, 82, 1, 69-78.

KÜRBIS, K., MUDELSEE, M., TETZLAFF, G., BRÁZDIL, R. (2009): Trends in extremes of temperature, dew point, and precipitation from long instrumental series from Central Europe. Theoretical and Applied Climatology, 98, 187-195.

KYSELÝ, J. (2010): Recent severe heat waves in central Europe: how to view them in a long-term prospect? International Journal of Climatology, 30, 89-109.

LAU, W.K.M., KIM, K.M. (2012): The 2010 Pakistan flood and Russian heat wave: Teleconnection of hydrometeorological extremes. Journal of Hydrometeorology, 13, 392-403.

LECKEBUSCH, G.C., ULBRICH, U. (2004): On the relationship between cyclones and extreme windstorms over Europe under climate change. Global and Planetary Change, 44, 181-193.

LECKEBUSCH, G.C., WEIMER, A., PINTO, J.G., REYERS, M., SPETH, P. (2008): Extreme wind storms over Europe in present and future climate: a cluster analysis approach. Meteorologische Zeitschrift, 17, 67-82.

MATSUEDA, M. (2011): Predictabilityof Euro-Russian blocking in summer of 2010. Geophysical Research Letters, 38, L06801. doi:10.1029/2010GL046557.

MEEHL, G.A., TEBALDI, C. (2004): More intense, more frequent, and longer lasting heat waves in the $21^{\text {st }}$ century. Science, $305,994-997$.

NIEDŹWIEDŹ, T. (1981): Synoptic situations and their influence on spatial differentiation of the selected climatic elements in the Upper Vistula basin. Rozprawy Habilitacyjne Uniwersytetu Jagiellońskiego, 58, Kraków.

NIEDŹWIEDŹ, T. (2003): Słownik meteorologiczny (ed.). PTGeof/IMGW, Warszawa.

OTTO, F.E.L., MASSEY, N., VAN OLDENBORGH, G.J., JONES, R.G., ALLAN, M.R. (2012): Reconciling two approaches to attribution of the 2010 Russian heat wave. Geophysical Research Letters, 39, L04702. doi: 10.1029/2011GL05042.

OZHEREDOV, V.A., BREUS, T.K., GURFINKEL, YU.I., REVICH, D.A., MITROFANOVA, T.A. (2010): Influence of some weather factors and geomagnetic activity on the development of severe cardiological pathologies. Biophysics, 55, 1, 110-119.

PAI, D.S., NAIR, S.A., RAMANATHAN, A.N. (2013): Long term climatology and trends of heat waves over India during the recent 50 years (1961-2010). Mausam, 64, 4, 585-604.

PETERSON, T.C. et al. (2013): Monitoring and understanding changes in heat waves, cold waves, floods, and droughts in the United States: State of knowledge. Bulletin of the American Meteorological Society, 94, 6, 821-834. 
PONGRÁCZ, R., BARTHOLY, J., BARTHA, E.B. (2013): Analysis of projected changes in the occurrence of heat waves in Hungary. Advances in Geosciences, 35, 115-122.

PORĘBSKA, M., ZDUNEK, M. (2013): Analysis of extreme temperature events in Central Europe related to high pressure blocking situations in 2001-2011. Meteorologische Zeitschrift, $22,5,533-540$.

POUMADERE, M., MAYS, C., LE MER, S., BLONG, R. (2005): The 2003 Heat Waves in France: Dongerous Climate Change Here and Now. Risk Analysis 25, 6, 1483-1494.

REBETEZ, M., DUPONT, O., GIROUD, M. (2006): An analysis of the July 2006 heatwave extent in Europe compared to the record year of 2003. Theoretical and Applied Climatology, 95, $1-2,1-7$.

REVICH, B.A., SHAPOSHNIKOV, D.A., PODOL'NAYA, M.A., KHOR'KOVA, T.L., KVASHA, E.A. (2015): Heat Waves in Southern Cities of European Russia as a Risk Factor for Premature Mortality. Studies on Russian Economic Development, 26, 2, 142-150.

SCHNEIDEREIT, A., SCHUBERT, S., VARGIN, P., LUNKEIT, F., ZHU, X., PETERS, D., FRAEDRICH, K. (2012): Large scale flow and the long-lasting blocking high over Russia: Summer 2010. Monthly Weather Review. doi:10.1175/MWR-D-11-00249.1.

SHEVCHENKO, O., LEE, H., SNIZHKO, S., MAYER, H. (2014): Long-term analysis of heat waves in Ukraine. International Journal of Climatology, 34, 1642-1650.

SHAPOSHNIKOV, D., REVICH, B., BELLANDER, T., BEDADA, G.B., BOTTAI, M., KHARKOVA, T. et al. (2014): Mortality related to air pollution with the Moscow heat wave and wildfire of 2010. Epidemiology (Cambridge, Mass), 25, 3, 359-364.

SPINONI, J., LAKATOS, M., SZENTIMREY, T., BIHARI, Z., SZALAI, S., VOGT, J., ANTOFIE, T. (2015): Heat and cold waves trends in the Carpathian Region from 1961 to 2010. International Journal of Climatology. doi: 10.1002/joc.4279.

TOMCZYK, A.M. (2014): Cyrkulacyjne uwarunkowania występowania fal upałów w Poznaniu (Circulation-related conditioning of the occurrence of heatwaves in Poznań). Przegląd Geograficzny, 86, 1, 41-52.

TOMCZYK, A.M., BEDNORZ, E. (2014a): Heat and cold waves on the southern coast of the Baltic Sea. Baltica, 27, 1, 45-53.

TOMCZYK, A.M., BEDNORZ, E. (2014b): Warm waves in north-western Spitsbergen. Polish Polar Research, 35, 3, 497-511.

TOMCZYK, A.M., BEDNORZ, E. (2016): Heat waves in Central Europe and their circulation conditions. International Journal of Climatology, 36, 2, 770-782.

TOMCZYK, A.M., PIOTROWSKI, P., BEDNORZ, E. (2016): Heat waves in Northern Europe in relation to atmospheric circulation. Theoretical and Applied Climatology. doi: 10.1007/ s00704-015-1727-0.

TWARDOSZ, R., KOSSOWSKA-CEZAK, U. (2013): Exceptionally hot summers in central and eastern Europe (1951-2010). Theoretical and Applied Climatology, 112, 617-628.

TWARDOSZ, R., KOSSOWSKA-CEZAK, U. (2015): Exceptionally hot and cold summers in Europe (1951-2010). Acta Geophysica, 63, 1, 275-300.

UNKAŠEVIĆ, M., TOŠIĆ, I. (2009): An analysis of heat waves in Serbia. Global and Planetary Change, 65, 17-26.

UNKAŠEVIĆ, M., TOŠIĆ, I. (2015): Seasonal analysis of cold and heat waves in Serbia during the period 1949-2012. Theoretical and Applied Climatology, 120, 29-40.

USTRNUL, Z., CZEKIERDA, D., WYPYCH, A. (2010): Extreme values of air temperature in Poland according to different atmospheric circulation classifications. Physics and Chemistry of the Earth, 35, 429-436. 
WARD, J.H. (1963): Hierarchical grouping to optimize an objective function. Journal of the American Statistical Association, 58, 236-244.

YARNAL, B. (1993): Synoptic Climatology in Environmental Analysis. Belhaven Press, London. ZACHARIAS, S., KOPPE, CH., MÜCKE, H.-G. (2015): Climate change effects on heat waves and future heat wave-associated IHD mortality in Germany. Climate, 3, 1, 100-117.

\section{SHRNUTÍ}

\section{Atmosférická cirkulace během horkých vln ve východní Evropě}

Cílem práce je charakteristika horkých vln ve východní Evropě a popis synoptických situací způsobujících jejich výskyt. S ohledem na velké riziko pro zdraví a život člověka, jaké je spojeno s výskytem horkých vln, a s ohledem na vysoké sociální i ekonomické náklady důsledků horkých vln mohou být prezentované výsledky zajímavé pro širokou a různorodou skupinu odběratelů.

Ve studii byly použity denní údaje týkající se maximální a minimální teploty vzduchy pro 33 stanic nacházejících se ve východní Evropě (Bělorusko, Estonsko, Litva, Lotyšsko, Rusko, Ukrajina) v období let 1973 až 2010. Údaje byly získány ze všeobecně dostupných databází NOAA.

V této studii je za horký den považován den s $T_{\max }$ ve výše nad hodnotu 95ročního percentilu, zatímco za vlnu veder řadu minimálně 5 takových dnů. Ve zkoumaném časovém období několika let hodnota 95ročního percentilu na hodnocené oblasti pohybovala od 20,4 ${ }^{\circ} \mathrm{C}$ (Murmansk) do $33,7^{\circ} \mathrm{C}$ (Alexandrov Gay).

Na základě zdrojových údajů byly vypočítány základní klimatologické charakteristiky, tj. maximální průměrná teplota vzduchu pro letní sezóny a počet horkých dnů. Následně byla z vybraných dnů určena vlna veder a byla posouzena jejich variabilita v časovém období několika let, byly vypočítány lineární trendy a zkontrolována jejich statistická významnost.

Pro charakteristiku barických podmínek př́iznivých pro výskyt vlny veder byly použity pravidelné denní hodnoty tlaku při hladině moře, výšky izobarické plochy $500 \mathrm{hPa}$ a teploty na izobarické ploše $850 \mathrm{hPa}$ (T850). Údaje pocházejí ze sbírek National Center for Environmental Prediction / National Center for Atmospheric Research (NCEP/NCAR) Reanalysis (Kalnay et al. 1996), které jsou dostupné v pramenech Climate Research Unit. Výše uvedené údaje posloužily pro sestrojení mapy tlaku při hladině moře, s500 hPa a T850 pro letní sezónu (VI-VIII), souhrnné mapy pro horké dny tvořící vlnu veder a vyčleněné typy cirkulace. Vyčlenění typů cirkulace bylo provedeno seskupením horkých dnů z hlediska hodnoty tlaku při hladině moře, s použitím metody minimálních variancí, známé jako Wardova metoda.

V letech 1973 až 2010 ve východní Evropě činila průměrná hodnota $T_{\max } v$ letní sezóně $22,8^{\circ} \mathrm{C}$ a pohybovala se od $15,0^{\circ} \mathrm{C}$ v Murmansku po $29,1^{\circ} \mathrm{C}$ v obci Alexandrov Gay. U zkoumaného časového období několika let bylo průměrně nejteplejší léto zaznamenáno v roce 2010 a průměrná $T_{\max }$ se v tuto sezónu pohybovala od $15,7^{\circ} \mathrm{C}$ (Murmansk) po $35,4^{\circ} \mathrm{C}$ (Alexandrov Gay). Při analýze průměrné $T_{\max }$ naměřené $v$ jednotlivých stanicích lze konstatovat, že léto $v$ roce 2010 bylo nejteplejší hlavně v Rusku a na Ukrajině. Výzkumy prokázaly na převážném prostoru statisticky významný nárůst $T_{\max }$, který se pohyboval od $0,30^{\circ} \mathrm{C} / 10$ let (Archangelsk) po 1,07 ${ }^{\circ} \mathrm{C} / 10$ let (Simferopol).

Průměrný počet dnů v sezóně se na jednotlivých stanicích pohyboval od 16 do 21 dní. U 70 \% stanic bylo nejvíce horkých dnů zaznamenáno v létě roku 2010. Ve výše uvedeném sezóně se jejich počet pohyboval od 19 (Pečora) po 67 (Charkov, Kursk). Pouze v Pečoře nejvyšší počet horkých dnů v sezóně nebyl zaznamenán v první dekádě 21. století, ale v roce 1974 (34 dní). 
Nejméně horkých dnů bylo zaznamenáno hlavně v 70. a 90. letech 20. století. Nejvíce horkých dnů bylo zaznamenáno v červenci a srpnu, které tvořily průměrně $40 \%$ a $27 \%$ všech horkých dnů. Tyto dny byly u většiny stanic zaznamenány v období od dubna do zárí nebo října (v případě 8 stanic). V analyzovaném období ve východní Evropě činil průměrný př́růstek počtu horkých dnů 4,5 dne za 10 let a byl statisticky významný. Největší nárůst počtu horkých dnů byl zaznamenán v Simferopolu (8,4 dny / 10 let) a Doněcku (8,0 dní / 10 let), zatímco nejmenší v Pečoře (0,6 dne / 10 let).

V posuzovaných letech bylo ve zkoumané oblasti zjištěno od 24 (Kaliningrad) do 55 (Charków) horkých vln. Nejméně horkých vln bylo průměrně zaznamenáno v letech 1973-1980, nejvíce v první dekádě 21 . století. Ve zkoumaném časovém období několika let se vlny veder vyskytovaly od května do záŕí, ačkoliv nejčastěji byly zaznamenány v červenci (průměrně $47 \%$ všech vln veder). Nejdřívější vlna veder v analyzovaném časovém období několika let byla zaznamenána v Brestu od 30. dubna do 4. května 1977, zatímco nejpozdější v Soči od 15. do 21. záŕí 1994. Z výše uvedených údajů vyplývá, že ve východní Evropě potenciální období výskytu vlny veder činilo 145 dní od 30. dubna do 21 . záŕí. U $76 \%$ stanic byly vlny veder nejčastěji zaznamenány v délce 5 dnů, přičemž u 21 \% stanic se jednalo o šestidenní vlny veder. Nejdelší horká vlna byla zaznamenána v Moskvě v roce 2010, která trvala celých 45 dnů. Při této horké vlně činila průměrná maximální teplota $33^{\circ} \mathrm{C}$, avšak průměrná minimální teplota $20^{\circ} \mathrm{C}$. V průběhu popisované horké vlny lze specifikovat dvě období s extrémně vysokou teplotou, tj. od 22. do 29. července a od 2. do 11. srpna. Výše uvedená období byla rozdělena 3denním ochlazením (ovšem s $T_{\max }>30^{\circ} \mathrm{C}$ ) způsobeným přechodem studené fronty. Výskyt horké vlny byl spojen s pásem vysokého tlaku vzduchu situovaným nad východní částí kontinentu. Tehdy byly zaznamenány pozitivní tlakové anomálie na hladině moře a v izobarické ploše $500 \mathrm{hPa}$, a také pozitivní anomálie T850.

Závěrem lze konstatovat, že provedené výzkumy ve východní Evropě prokázaly nárůst průměrné maximální teploty vzduchu v letní sezóně, jakož i nárůst častějšího výskytu horkých dnů. Důsledkem výše uvedených změn byly stále častější vlny veder, které byly nejpočetnější v první dekádě 21. století. Ve zkoumaném období byl zejména extrémní rok 2010, v němž byly překročeny dlouholeté rekordy.

Obr. 1 Lokalizace meteorologických stanic

Obr. 2 Hodnota 95ročního percentilu $T_{\max }\left({ }^{\circ} \mathrm{C} ; \mathrm{a}\right)$, průměrná $T_{\max }\left({ }^{\circ} \mathrm{C}\right)$ v létě (červen-srpen; b), změny průměrné letní $T_{\max } \mathrm{V}^{\circ} \mathrm{C} / 10$ let (c), za období 1973-2010

Obr. 3 Průměrná letní $T_{\max }\left({ }^{\circ} \mathrm{C}\right.$; černá čára) s trendovou linií a regresní rovnicí a odchylky $T_{\max }$ od průměrné $T_{\max }\left({ }^{\circ} \mathrm{C}\right)$ ve víceletém období 1973-2010 (šedivé sloupce) na vybraných stanicích

Obr. 4 Víceleté řady ročního počtu horkých dní s linií trendu a s regresní rovnicí na vybraných stanicích

Obr. 5 Prostorový model celkového počtu horkých vln (přerušované čáry), a celková doba trvání horkých vln (plné čáry), v letech 1973-2010

Obr. 6 Datum zahájení nejbližší horké vlny (a), datum ukončení poslední horké vlny (b), délka doby možné př́tomnosti horké vlny (c)

Obr. 7 Průměrné letní (červen-srpen) hodnoty tlaku při hladině moře (SLP; hPa; plné čáry) a Z500 hPa (m; přerušované čáry; a) a T850 ( $\left.{ }^{\circ} \mathrm{C} ; \mathrm{b}\right)$

Obr. 8 Průměrné hodnoty tlaku při hladině moře (SLP; hPa; plné čáry) a Z500 hPa (m; přerušované čáry; a), hodnoty tlaku při hladině moře (SLP; hPa; plné čáry) a odchylky Z500 $\mathrm{hPa}\left(\mathrm{m}\right.$; přerušované čáry; b) a odchylky T850 ( $\left.{ }^{\circ} \mathrm{C} ; \mathrm{c}\right)$ na dny horkých vln 
Obr. 9 Průměrné hodnoty tlaku při hladině moře (SLP; hPa; plné čáry) a Z500 hPa (m; přerušované čáry; a), hodnoty tlaku při hladině moře (SLP; hPa; plné čáry) a odchylky Z500 hPa es (m; přerušované čáry; b) a odchylky T850 ( $\left.{ }^{\circ} \mathrm{C} ; \mathrm{c}\right)$ pro přehledné typu 1 a 2 způsobují horké vlny

Obr. $10 T_{\max }\left({ }^{\circ} \mathrm{C}\right.$; nepřerušovaná čára) a odchylky od $T_{\max }\left({ }^{\circ} \mathrm{C}\right) \mathrm{z}$ průměrné hodnoty $T_{\max }$ ve víceletém období 1973-2010 (šedivé sloupce) v Moskvě

Obr. 11 Průměrné hodnoty tlaku při hladině moře (hPa; plné čáry) a Z500 hPa ( $\mathrm{m}$; přerušované čáry; a), hodnoty tlaku při hladině moře (hPa; plné čáry) a odchylky Z500 hPa (m; přerušované čáry; b), a odchylky T850 $\left({ }^{\circ} \mathrm{C}\right.$; c) pro horké vlny za rok 2010

\section{ACKNOWLEDGEMENTS}

This work was partly supported by the Polish National Science Centre under grant number: UMO-2014/15/N/ST10/00717. 